Sains Malaysiana 46(4)(2017): 575-581

http://dx.doi.org/10.17576/jsm-2017-4604-09

\title{
Low Intensity Ultrasound Induced Apoptosis in MCF-7 Breast Cancer Cell Lines
}

(Ultrabunyi Keamatan Rendah Aruhan Apoptosis dalam Jujukan Sel Kanser Payudara MCF-7)

\author{
SiTI P.M. BOHARI*, HAMIDREZA ABOULKHEYR, E.S., NUR S. JOHAN \& NURSYUHADA F. ZAINUDIN
}

\begin{abstract}
According to the World Cancer Research Fund International (WCRFI), breast cancer is the most common type of cancer in women worldwide with recorded 1.7 million new cases in 2012. The main line of treatments is still limited to chemotherapy, surgery and radiotherapy which could lead to a wide range of dangerous side effects. This study was conducted to evaluate the effect of low intensity ultrasound (LIUS) on cell proliferation, percentage of living and dead cells and the induction of apoptosis on the MCF-7 cell line with CHO cells as the control for non-cancerous group. In order to achieve the objective of this study, several methods of cell-bioguided assays were used including the MTT assay for cell proliferation, Livel Dead assay for the determination of both live and dead cells and gene expression study for the detection of apoptosis in the cells. The cytotoxicity and Live/Dead assays data provided preliminary data that the LIUS has potential to induce apoptosis in a wide population of breast cancer cells. Furthermore, the LIUS treatment induced the expression of p53MRNA at a detectable level via qPCR analysis, indicating the activation of apoptosis. In short, our study suggested LIUS dosage used in this study could potentially show positive effects in the induction of apoptosis selectively on the MCF-7 with less harm to the control CHO cells.
\end{abstract}

Keywords: Apoptosis; CHO cells; LIUS; MCF-7 cells; qPCR

\section{ABSTRAK}

Merujuk kepada 'World Cancer Research Fund International' (WCRFI), kanser payudara adalah jenis kanser yang paling umum pada wanita di seluruh dunia dengan catatan rekod 1.7 juta kes baru pada 2012. Rawatan utama masih lagi terhad kepada kimoterapi, pembedahan dan radioterapi yang boleh membawa kepada pelbagai kesan sampingan berbahaya. Penyelidikan ini dijalankan untuk menilai kesan ultrabunyi berkeamatan rendah (LIUS) pada pertumbuhan sel, peratusan hidup dan mati sel dan juga pengaruhan 'apoptosis' pada jujukan sel MCF-7 dan CHO sebagai kumpulan kawalan sel bukan kanser. Untuk mencapai objektif di dalam kajian ini, beberapa kaedah bioasai berdasarkan sel telah digunakan termasuklah asai MTT untuk pertumbuhan sel, asai 'Live/Dead' untuk pengenalpastian hidup dan mati sel dan juga kajian ekspresi gen untuk pengesanan 'apoptosis' pada sel. Asai sitotoksiti dan 'Live/Dead' menggambarkan data awal bahawa LIUS berpotensi untuk mengaruh 'apoptosis' di dalam populasi yang besar bagi kanser payudara. Tambahan lagi, rawatan LIUS juga berpotensi untuk mengaruh ekspresi p53-mRNA pada aras yang dapat dikesan melalui analisis qPCR yang menunjukkan pengaktifan 'apoptosis. Kesimpulannya, kajian kami mencadangkan dos LIUS yang digunakan dalam kajian ini berpotensi dalam menunjukkan kesan positif dalam pengaruhan 'apoptosis' pilihan pada sel MCF-7 dengan sedikit kemudaratan kepada sel CHO.

Kata kunci: Apoptosis; LIUS; qPCR; sel CHO; sel MCF-7

\section{INTRODUCTION}

Breast cancer is the second most reported case of cancer in women, worldwide. In order to control and suppress growth of breast cancer, the treatment regimen available nowadays is limited to chemotherapy, radiotherapy, surgery (Guo 2014; Hortobagyi et al. 2005) and hormone therapy, where estrogen and progesterone receptors detected on cancer cells will be targeted for hormone receptor blockers. Recent studies suggested new effective approaches in the treatment of breast cancer by employing small molecule inhibitors in combination and/or in sequence with radioand chemotherapy compounds, rendering high efficiency of the treatment and increasing the overall survival of patients (Garg \& Buchholz 2015; Komen et al. 2008). In addition to these new approaches, employing alternative methods such as ultrasound (US), sonodynamic (SDT), photodynamic therapy (PDT) and hyperthermia treatment can increase the prospect of treating breast cancer through the induction of apoptosis ( $\mathrm{Li}$ et al. 2012). Ultrasound is defined as a mechanical vibration produced via sound wave with the frequency of more than $20 \mathrm{kHz}$ (Wood \& Sehgal 2015). It is well-noted that the effective therapeutic frequency of ultrasound is in the range of 0.8 to $3 \mathrm{MHz}$ (Cambier et al. 2001; Wu \& Nyborg 2006). Physically, the result of this continuous sound wave could lead to cell damage via cavitation (Ninomiya et al. 2014) and by increasing the temperature of the cell microenvironment (Cambier et al. 2001; Johns 2002; Larina et al. 2005; Shibaguchi et al. 2011). 
Previously, the combination treatment using ultrasound with a 5-Fluorouracil drug increased the expression of apoptotic protein. However, addition of the Optison drug, resulted in suppression of the apoptotic protein expression (Chumakova et al.2006). In addition, recent studies showed that the use of ultrasound technique together with chemotherapy drug such as Cisplatin could potentially induce apoptosis in cancer cells (Li et al. 2012). In this study, we used low intensity ultrasound to induce apoptosis independently without combination with any chemotherapy drug.

\section{MATERIALS AND METHODS}

\section{MATERIALS}

Roswell Park Memorial Institute (RPMI) 1640 medium with $2 \%$ L-Glutamine were purchased from Biowest (Puchong, Selangor, Malaysia). Phosphate Buffer Saline (PBS) and Propidium Iodide for Live/Dead Assay were purchased from Sigma-Aldrich (Subang Jaya, Selangor, Malaysia). Trypsin was purchased from Gibco (Petaling Jaya, Selangor, Malaysia). The Trypan Blue solution was purchased from Bio-basic (Puchong, Selangor, Malaysia) and Calcein AM of Live/Dead assay was purchased from Life Technologies (Petaling Jaya, Selangor, Malaysia). 3-(4,5-dimethylthiazol-2,5-diphenyl tetrazolium bromide (MTT) was purchased from Sigma-Aldrich Group (Petaling Jaya, Selangor, Malaysia). RNA Isolation Kit, Thermo Scientific Maxima Reverse Transcriptase and SYBR Green were purchased from Thermo Fisher Scientific (Shah Alam, Selangor, Malaysia). Trypsin/EDTA was purchased from Gibco (Petaling Jaya, Selangor, Malaysia). The penicillin/ streptomycin antibiotic for cell culture were purchased from Gibco (Petaling Jaya, Selangor, Malaysia).

\section{CELL CULTURE}

The breast cancer cell lines, MCF-7 and non-cancerous cells, CHO (Chinese Hamster Ovary) used as a control, were purchase from American types of cancer cell, ATCC (USA) and was a generous gift from Dr Sallehuddin Hamdan from the Animal Tissue Culture Laboratory, Faculty of Biosciences and Medical Engineering, Universiti Teknologi Malaysia. The cells were cultured in RPMI-1640 supplemented with $10 \%$ FBS and $1 \%$ Pen/Strep, incubated in $\mathrm{CO}_{2}$ incubator at $37^{\circ} \mathrm{C}$.

\section{OPTIMIZING SEEDING DENSITY}

The cancer cells (MCF-7) were trypsinized and seeded into six-well plate containing RPMI 1640 with the seeding densities ranging from $5 \times 10^{5}$ to $1 \times 10^{6}$ cells $/ \mathrm{mL}$. The same procedure was performed for $\mathrm{CHO}$ (as the non-cancerous control cells) with seeding densities of $4 \times 10^{5}$ to $9 \times 10^{5}$ cells $/ \mathrm{mL}$ as the $\mathrm{CHO}$ cells proliferate faster than MCF-7 cells. The cells were then incubated in the $\mathrm{CO}_{2}$ incubator until it reaches $70-80 \%$ confluence. The optimum seeding densities (70-80\% confluency) for both cells were observed and chosen for the LIUS experiment.

\section{ULTRASOUND TREATMENT}

A Sonopuls 491 (Enraf-Nonius, Rotterdam, Amsterdam) ultrasound source was used in this study. Its transducer was immersed in a water bath filled with deionized water maintained at $37^{\circ} \mathrm{C}$ and the water was changed every day. The 6-well plate containing cells (MCF-7 cells were plated at $1 \times 10^{6}$ cells/well while $\mathrm{CHO}$ at $4 \times 10^{5}$ cells/well) was placed on top of the transducer while the control group was maintained in the same conditions without being exposed to the ultrasound. The ultrasound stimulation was performed 10 min every day for 3 days at the frequency of $1 \mathrm{MHz}$ and an intensity of $0.1 \mathrm{~W} / \mathrm{cm}^{2}$. Treated and control samples were analyzed after 1,2 and 3 days to determine the cells proliferation, percentage of live/dead cells and the induction of apoptosis; at each time period results for each analysis were obtained from 3 different samples.

\section{CYTOTOXICITY ASSAY}

MTT assay was performed on 3 days interval for both MCF 7 and CHO cells. MTT solution $(5 \mathrm{mg} / \mathrm{mL})$ was prepared in PBS buffer. The media was discarded and the freshly prepared $250 \mu \mathrm{L}$ of MTT solution and $1750 \mu \mathrm{L}$ of media were added to each well containing the cells and left for $4 \mathrm{~h}$ in the $\mathrm{CO}_{2}$ incubator. After that, the precipitate was dissolved with $4.5 \mathrm{~mL} 1 \mathrm{NHCl} /$ Isopropanol and left for $15 \mathrm{~min}$ for the formazan to be dissolved. The absorbance was read at a wavelength of $570 \mathrm{~nm}$ using a microplate reader (Epoch-Micro, Bio-Tek Instruments, USA) (Uludag $\&$ Sefton 1990). The samples were done in triplicate for both the control and the treated cells for 3 days interval.

\section{LIVE-DEAD ASSAY}

Live and Dead assay was done by using a method previously described (Bohari et al. 2011) with slight modification. The control and treated groups were visualized using the inverted microscope (Nikkon Eclipse TS 100, Nikon Instrument Inc. USA) every day for 3 days interval after the ultrasound exposure. After 3 days, the media in each well was discarded and $1 \mathrm{~mL}$ of PBS was added to wash the cells. $300 \mu \mathrm{L}$ of trypsin was added into the wells after the PBS solution was discarded. The cells were incubated for $5 \mathrm{~min}$ in the $\mathrm{CO}_{2}$ incubator to allow cells detachment. Then, $700 \mu \mathrm{L}$ media was added into each well and the cell suspension was transferred into $1.5 \mathrm{~mL}$ microcentrifuge tube. Propidium Iodide $(25 \mu \mathrm{L}$, $150 \mu \mathrm{M})$ and Calcein AM $(2 \mu \mathrm{L}, 100 \mu \mathrm{M})$ were added into each microcentrifuge tube and re-suspended. The cell suspensions were incubated for 15-20 min at room temperature in the dark for the staining purposes. Then, $40 \mu \mathrm{L}$ of the stained cell suspension were transferred onto glass slides and covered with coverslip. The images of the stained cells under the fluorescence microscope (Nikon Eclipse-Ti-S Inverted Microscope System, New York, USA) were captured and the percentage of live/dead cells were counted. 


\section{REAL-TIME PCR ASSAY}

Total RNA was isolated from the treated cancer cells and the control cells by using the RNA isolation kit (GeneJET RNA purification kit. Thermo Fischer Scientific, USA) according to the manufacturer's instructions. cDNA was synthesized using Maxima Reverse Transcriptase Kit (Thermo Fischer Scientific, USA. cat\#EP0742). The standard curves were obtained using serial dilutions of the cDNA and beta-actin (House Keeping Gene). Quantitative Real-Time-PCR assay was performed based on the SYBR Green (Maxima SYBR Green qPCR Master Mix, Thermo Fisher Scientific, USA cat\# K0252). Genespecific primers were obtained from Integrated DNA Technologies (Iowa, USA). The p53 forward primer: 5'AGCATCTTATCCGAGTGGAAGGAA-3' and Reverse sequence: 5'-TTATGGCGGGAGGTAGACTGACC-3', for $\beta$-actin, Forward: 5'- GATGGTGGGAATGGGTCAGA-3', Reverse: 5'- GGAGAGCATAGCCCTCGTAGAT-3'. The gene expression values obtained were normalized using a housekeeping gene copy numbers of mRNA which were calculated from the serially diluted standard curves generated from the cDNA template.

\section{STATISTICAL ANALYSIS}

The Shapiro-Wilk test (Pallant 2007) for the normality test was done for all of the data. The data were analysed using Mann-Whitney test for Non-normal data and Independent $t$-test for normal data (Pallant 2007). The differences were considered significant if $p<0.05$.

\section{RESULTS}

\section{EFFECT OF CONTINUOUS LOW INTENSITY ULTRASOUND TREATMENT ON CELLS PROLIFERATION}

The exposure of therapeutic ultrasound on MCF-7 cells was investigated in the duration of three day intervals. As shown in Figure 1(a), the reading patterns for the control and treatment groups increased from Day 1 up to Day
3. However, the number of cancer cells in the treatment group was less compared to the control group. This showed that the mechanical vibration generated by the ultrasound exposure inhibited the proliferation of the cancer cells and caused a decrease in the number of cells throughout the course of the study (Watanabe et al. 2002). However, for CHO cells as shown in Figure 1(b), ultrasound exposure to the treatment group had little or no deleterious effect to the cells; as seen when compared to the control group. From the quantitative analysis shown in Figure 1(c), the percentage inhibition of MCF-7 cells increased from Day 1 to Day 3. Almost more than half of the total inhibition was observed in MCF-7 cells while $\mathrm{CHO}$ cells showed less than $1 \%$ of growth inhibition. A possible explanation is that malignant cells such as the breast cancer cells were highly susceptible to growth retardation by ultrasound ( $\mathrm{Li}$ et al. 2012; Wang et al. 2013).

Previous studies have generalized the effect of ultrasound on normal cells; in vivo studies by Nonaka et al. (2009) showed that ultrasound selectively killed tumor without damaging the intervening or surrounding normal brain tissues in rats. The activation of the ultrasonic exposure significantly enhanced the antitumor effect, without the risk of damaging normal intervening brain tissues (Nonaka et al. 2009). Naturally occurring cancer cells possessed higher entropy production rates. The ability of entropy to flow to the normal cell will transmit related information from the cancerous cell to the normal cells causing force malignancy. While ultrasound treatment reversed this direction, it will induce a reverse of the information from the healthy cell to the cancerous cell as cancer cell possessed higher absorption capability (Luo et al. 2013; Park et al. 2013).

As stated in a previous study, the therapeutic dosage of the ultrasound may not be in adequate amount to cease the growth of MCF-7 cells (Wang et al. 2013; Yu et al. 2004). In fact, bio-effects of ultrasound alone on cancer cells is tissue-dependent, suggesting that applying an identical ultrasound parameters for all types of tissue were not an effective approach. In contrast, employing an optimized (a)

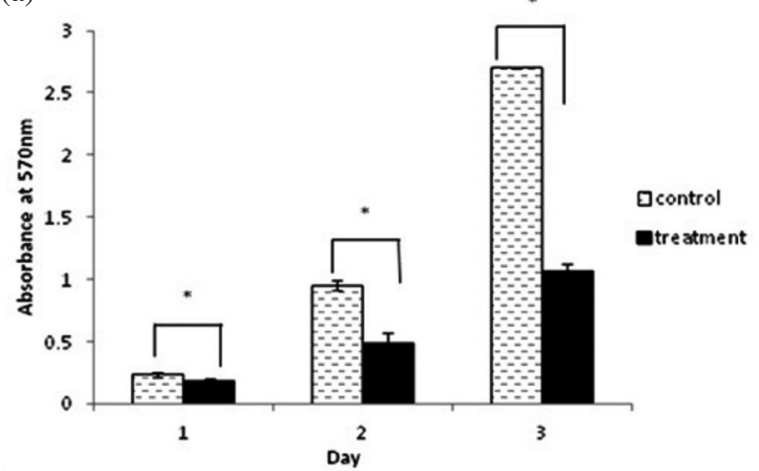

(b)

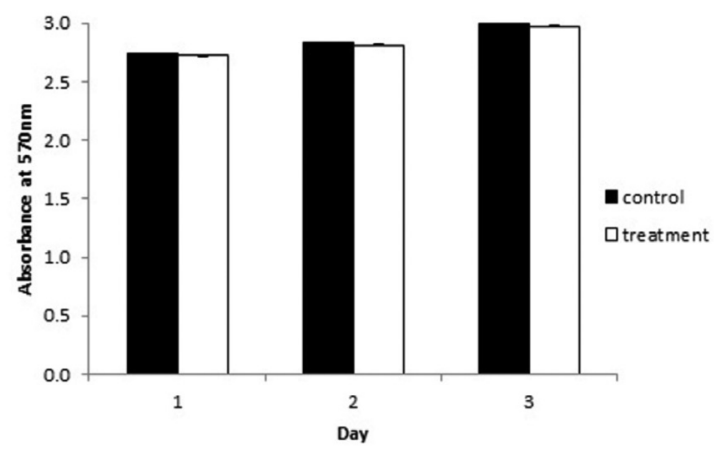

FIGURE 1. Cytotoxicity study on a) MCF-7 and b) CHO cells in three days interval after treatment with continuous therapeutic ultrasound. Each result indicated the mean of the three observations and the error bars represent the standard deviation. Results which are significantly different $(p<0.05)$ were marked with an asterisk* 


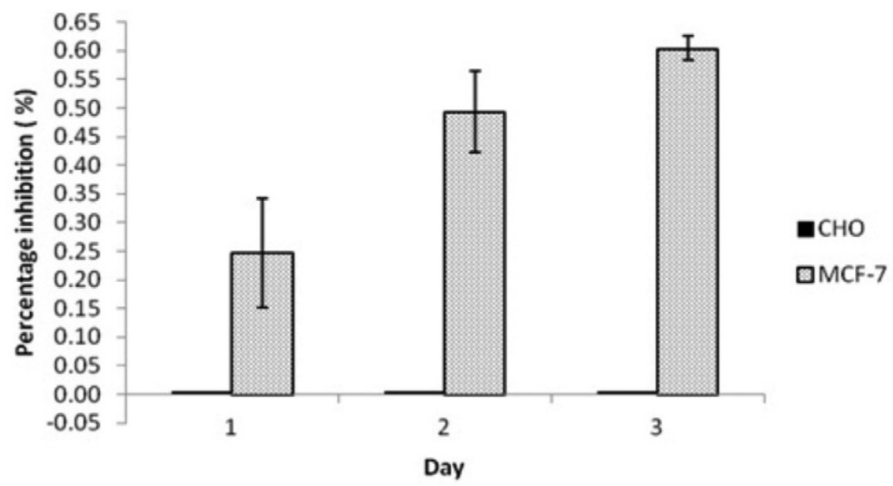

FIGURE 1(c). Percentage inhibition for both cells (CHO and MCF 7) for the period of three days.

The results are shown based on the specific calculation involving the control and treatment days. Error bars represent the standard deviation

ultrasound parameters can increase its bio-effects alone and or with the combination of cancer drugs (Wang et al. 2013; Yu et al. 2004).

LIVE/DEAD STAINING ON THE MCF-7 AND CHINESE HAMSTER OVARY (CHO) CELLS AFTER THE CONTINUOUS ULTRASOUND TREATMENT

During the $72 \mathrm{~h}$ ( 3 days) of ultrasound treatment, it can be seen that the treated MCF-7 cells showed the highest number of dead cells through the detection of red fluorescence cells when stained with Propidium Iodide (PI) instead of the green cells stained with Calcein AM (CAM) when compared to the control (Figure 2(a)). On the other hand, for the CHO cells, no significant differences were detected between the treated and non-treated cells (Figure 2(b)). The increasing number of MCF-7 cells taking up the PI stain could happen due to the presence of breakage or damaged cells in the population of the treated cells. Therefore, the number of dead cells that can be detected within the population increased. Meanwhile, only a few numbers of red fluorescent $\mathrm{CHO}$ cells were observed via the inverted fluorescence microscope. This shows that the therapeutic ultrasound did not affect the proliferation of normal cells due to the low rate of temperature absorption and heat transfer to the cancerous cells (Luo et al. 2006; Park et al. 2013).

Moreover, the control group of MCF-7 (cancerous cells) and $\mathrm{CHO}$ (non-cancerous cells) cells, also represents dead cells but it was very little when compared to the treated groups. This might probably happen due to the trypsinization and incubation process that may somehow induce damages to the cells during the preparation stage (Tsao et al. 1999).

The fluorescent images were captured and the viability percentage of MCF- 7 and CHO cells were calculated by using the formula below (Bohari et al. 2011):

Viability $(\%)=($ Total cells - Dead cells $) /$ Total cells $\times 100 \%$.

The viability of MCF- 7 after the exposure with the therapeutic ultrasound for 3 days treatment shows a decreased from 93\%, $90 \%$ and until $83 \%$, respectively (Figure 2(b)). However, for the treated CHO cells, the decrement was only $2 \%$ for the whole $72 \mathrm{~h}$ (Figure 2(b)). Moreover, statistical study did not show any significant different between treated and control $\mathrm{CHO}$ cells group. Therefore, the results clearly demonstrated the effect of the therapeutic dosage of ultrasound treatment on the growth of MCF-7 in contrary to a very minimal effect of the treatment on CHO cells.

Even though there was decrease in viability of the MCF-7 cells, the data showed a significance $p<0.01$ for the $24 \mathrm{~h}$ treatment of the treated MCF-7 compared to control. Whereas the treated MCF- 7 cells did not show any significant result after 48 and $72 \mathrm{~h}$.

The results obtained showed that the MCF-7 percentage of viability has reduced compared to non- cancerous cell lines $\mathrm{CHO}$ which has an approximately constant percentage of viability. As proposed earlier, MCF-7 cells was more susceptible towards retardation or inhibition of growth when exposed to ultrasound treatment compared to the normal cells (Jia et al. 2015; Lejbkowicz \& Salzberg 1997). Thus, with this specific intensity, the therapeutic ultrasound treatment has the possibility to disrupt the MCF-7 membrane (Furusawa et al. 2012; Symmans et al. 2000); subsequently induce biological damage caused by the cavitation process due to the applied heat (Miller et al. 2012). As a result from the mechanical stress of therapeutic ultrasound, cell to cell attachment was disrupted which led to apoptosis and increased the cell membrane permeability towards PI staining (Darzynkiewicz et al. 1992; Rieger et al. 2011; Vermes et al. 2000, 1995).

\section{APOPTOTIC PROTEIN DETECTION}

Ultrasound has been shown to induce apoptosis in many experimental systems. Thus, in the present study, we attempted to detect p53 which is the key apoptosis element at mRNA level in order to evaluate whether ultrasound could induce apoptosis in MCF-7 with less harm to the control $\mathrm{CHO}$ cells. The occurrence of apoptosis was estimated by real-time PCR analysis of p53-mRNA. High expression level of p53-mRNA was detected in the first $24 \mathrm{~h}$ after ultrasound 

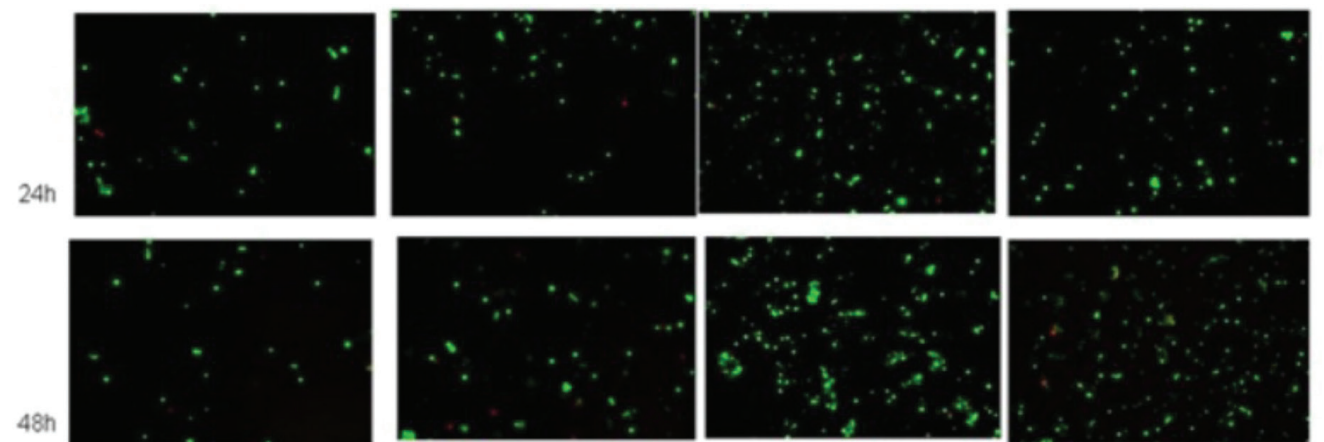

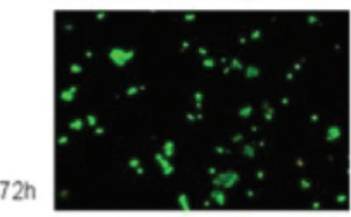

Control Group

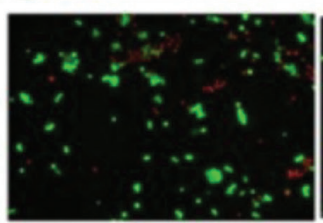

Treatment Group

MCF-7 cell lines

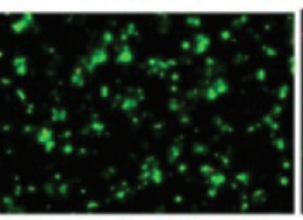

Control Group

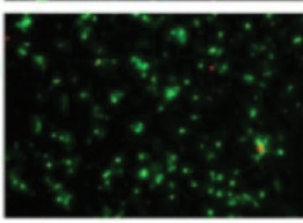

Treatment Group

CHO cell lines

\section{$100 \mu \mathrm{m}$}

FIGURE 2(a). Live and dead assay staining showed viable (green) and dead (red) cells for MCF-7 and CHO cell lines; $24 \mathrm{~h}, 48 \mathrm{~h}$ and $72 \mathrm{~h}$

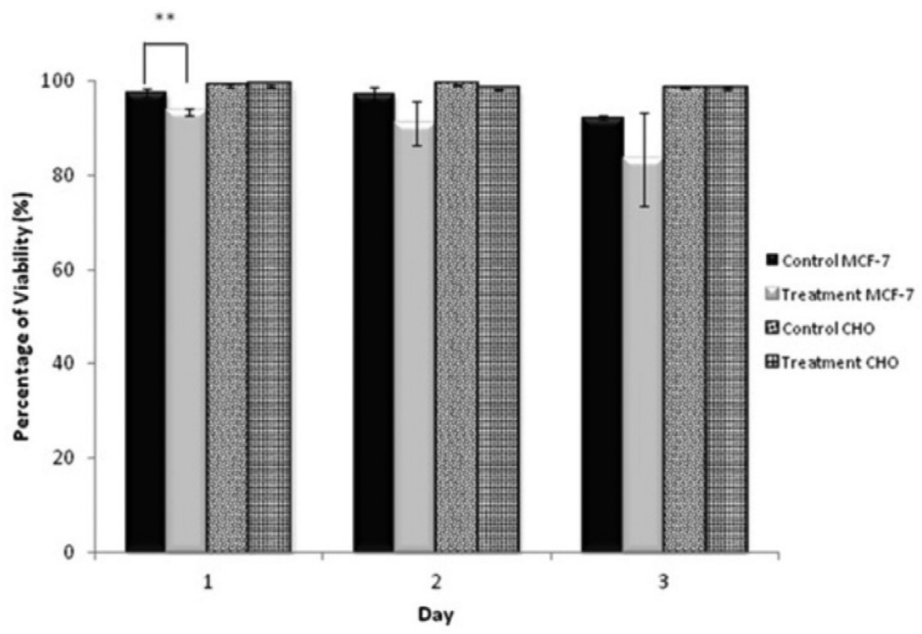

FIGURE 2(b). Percentage of viability of the MCF-7 and CHO viable cells, measured from the specimens stained with Propidium Iodide and Calcein AM. Each results is the mean value of the triplicate observations and the error bars represented the standard deviation, $* * p<0.01$

treatment (Figure 3). Furthermore, after $72 \mathrm{~h}$ of incubation, MCF-7 cells showed gradual decrease of p53-mRNA while $\mathrm{CHO}$ cells showed no significant difference in the level of mRNA during the $72 \mathrm{~h}$. For the CHO cells, less amount of mRNA was detected after $24 \mathrm{~h}$ of treatment. This data suggested that ultrasound could induce apoptosis or cell death of the MCF-7 cells, but had no effects on normal and/ or healthy cells.

\section{DISCUSSION}

Apoptosis is characterized by a number of well understood features including the activation of related signalling pathways and their downstream proteins such as Caspases, p53 and $\mathrm{Rb}$. It is well understood that a wide range of intrinsic and extrinsic factors, signal-stimulus pathways and mechanical forces can activate apoptosis and its complex dynamic network (Li et al. 2012). Several studies have shown that ultrasound treatment, albeit a new approach, can potentially activate apoptosis (Dubinsky et al. 2008; Li et al. 2012; Wang et al. 2013) and/or increase the sensitivity of cancer cells for the uptake of chemotherapy drugs (Chumakova et al. 2006; Ninomiya et al. 2014).

These results demonstrated that ultrasound treatment at a specific dosage has the ability to inhibit proliferation of MCF7 cells. As shown in Figure 1(c), proliferation of MCF-7 cells was inhibited the most after $72 \mathrm{~h}$ of exposure. 


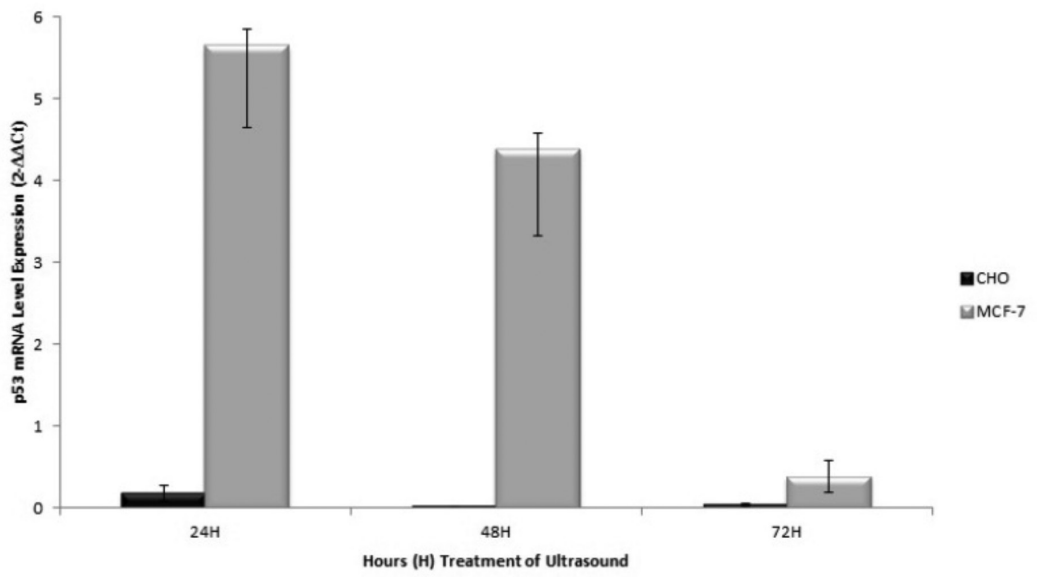

FIGURE 3. Real-time PCR analysis of p53-mRNA in breast cancer cells (MCF-7) and non-cancerous cells $(\mathrm{CHO})$ after $72 \mathrm{~h}$ incubation following the ultrasound treatment

The results obtained from the MTT assay which showed that exposure to the therapeutic dosage of ultrasound only inhibited proliferation of cancer cell line (MCF-7) without any significant inhibition to the normal cell line ( $\mathrm{CHO})$.

It is understood that ultrasonic hyperthermia may lead to its therapeutic effects by arresting the cancer cells in the $\mathrm{S}$ phase of the cell cycle and may have superior effects on hypoxic, acidic and malnourished tumor cells (Paliwal \& Mitragotri 2008). Previous study has generalized the effect of ultrasound on normal cells; in vivo studies by Nonaka et al. (2009) stated that ultrasound selectively killed tumor without damaging or intervening with the surrounding normal brain tissues in rats. Studies conducted by Luo et al. (2006) and Wang et al. (2013) also demonstrated that an appropriate and effective dosage may eliminate all of the cancer cells.

The microscopic analysis of the Live/Dead assay indicate the inhibitory effect of ultrasound on a wide range of cancerous cells compared to normal cells throughout the course of study (Figure 2(a) and 2(b)). Furthermore, the wavelength applied on MCF-7 cells did not show any significant effect after $24 \mathrm{~h}$ of treatment. This may have occurred due to the activation of anti-apoptotic signalling pathways on MCF-7 cells against the therapeutic ultrasound treatment.

In addition to these results and in relation to previous studies (Li et al. 2012), ultrasound treatment enhanced the level of p53-mRNA expression which can be detected by means of qPCR, indicating the induction of apoptosis and inhibition of cell growth (Figure 3). The large body of evidences indicated that cancer cell lines with wild type p53 are more sensitive when treated with apoptosis-based drugs and/or with the ultrasound treatment (Hupp et al. 2000). One possible reason is that, cancer cells with the mutated p53 show more stability of $\mathrm{p} 53$ protein at high level than the wild-type (Hui et al. 2006). Inversely, we demonstrated that the level of p53-mRNA decreased after $72 \mathrm{~h}$ while the inhibition of cancer cells increased (Figure 1(c)). This may have occurred as the ultrasound treatment activates another apoptosis mechanism. A recent study showed that ultrasound can induce apoptosis through the activation of Caspase- 3 and Caspase- 9 as the main component of apoptosis (Li et al. 2012).

Additionally, some signalling pathways responding to ultrasound-induced apoptosis were also suggested; for example, the mitochondrial pathway Bcl-2 family together with $\mathrm{p} 53$, and the oxidative stress signalling pathway accompanied with Heme-Oxygenase I and Heat Shock Proteins (Feng et al.2010). However, the exact mechanism of apoptosis via ultrasound is still unclear. Our study provided a new approach in eliminating malignant breast cancer cell by means of ultrasound alone. Further studies are required to understand the exact apoptosis mechanism through a continuous low intensity ultrasound.

\section{CONCLUSION}

In conclusion, findings from the study suggested that low intensity ultrasound at a specific dose has a significant effect in inducing apoptosis in breast cancer cells with minimal harm to normal cells.

\section{ACKNOWLEDGEMENTS}

This work was supported by Universiti Teknologi Malaysia grant (Grant No: GUP 08J15).

\section{REFERENCES}

Bohari, S.P.M., Hukins, D.W.L. \& Grover, L.M. 2011. Effect of calcium alginate concentration on viability and proliferation of encapsulated fibroblasts. Bio-Medical Materials and Engineering 21(3): 159-170.

Cambier, D., D’Herde, K., Witvrouw, E., Beck, M., Soenens, S. \& Vanderstraeten, G. 2001. Therapeutic ultrasound: Temperature increase at different depths by different modes in a human cadaver. Journal of Rehabilitation Medicine 33(5): 212-215.

Chumakova, O.V., Liopo, A.V., Evers, B.M. \& Esenaliev, R.O. 2006. Effect of 5-fluorouracil, optison and ultrasound on MCF-7 cell viability. Ultrasound in Medicine \& Biology 32(5): 751-758. 
Dubinsky, T.J., Cuevas, C., Dighe, M.K., Kolokythas, O. \& Hwang, J.H. 2008. High-intensity focused ultrasound: Current potential and oncologic applications. American Journal of Roentgenology 190(1): 191-199.

Feng, Y., Tian, Z. \& Wan, M. 2010. Bioeffects of low-intensity ultrasound in vitro apoptosis, protein profile alteration, and potential molecular mechanism. Journal of Ultrasound in Medicine 29(6): 963-974.

Garg, A.K. \& Buchholz, T.A. 2015. Influence of neoadjuvant chemotherapy on radiotherapy for breast cancer. Annals of Surgical Oncology 22(5): 1434-1440.

Guo, W. 2014. Concise review: Breast cancer stem cells: Regulatory networks, stem cell niches, and disease relevance. Stem Cells Translational Medicine 3(8): 942-948.

Hortobagyi, G.N., de la Garza Salazar, J., Pritchard, K., Amadori, D., Haidinger, R., Hudis, C.A., Hussein Khaled; Liu, M-C., Martin, M. \& Namer, M. 2005. The global breast cancer burden: Variations in epidemiology and survival. Clinical Breast Cancer 6(5): 391-401.

Hui, L., Zheng, Y., Yan, Y., Bargonetti, J. \& Foster, D.A. 2006. Mutant p53 in MDA-MB-231 breast cancer cells is stabilized by elevated phospholipase D activity and contributes to survival signals generated by phospholipase D. Oncogene 25(55): 7305-7310.

Hupp, T., Lane, D. \& Ball, K. 2000. Strategies for manipulating the p53 pathway in the treatment of human cancer. Biochem. J.352: 1-17.

Johns, L.D. 2002. Nonthermal effects of therapeutic ultrasound: The frequency resonance hypothesis. Journal of Athletic Training 37(3): 293-299.

Komen, J., Wolbers, F., Franke, H.R., Andersson, H., Vermes, I. \& van den Berg, A. 2008. Viability analysis and apoptosis induction of breast cancer cells in a microfluidic device: Effect of cytostatic drugs. Biomedical Microdevices 10(5): 727-737.

Larina, I.V., Evers, B.M. \& Esenaliev, R.O. 2005. Optimal drug and gene delivery in cancer cells by ultrasound-induced cavitation. Anticancer Research 25(1A): 149-156.

Li, Y., Wang, P., Zhao, P., Zhu, S., Wang, X. \& Liu, Q. 2012. Apoptosis induced by sonodynamic treatment by protoporphyrin IX on MDA-MB-231 cells. Ultrasonics 52(4): 490-496.

Luo, L., Molnar, J., Ding, H., Lv, X. \& Spengler, G. 2006. Ultrasound absorption and entropy production in biological tissue: A novel approach to anticancer therapy. Diagnostic Pathology 1(1): 35.

Ninomiya Kazuaki, Takahiro Yamashita, Shinya Kawabata \& Nobuaki Shimizu. 2014. Targeted and ultrasound-triggered drug delivery using liposomes co-modified with cancer cell-targeting aptamers and a thermosensitive polymer. Ultrasonics Sonochemistry 21(4): 1482-1488.
Paliwal, S. \& Mitragotri, S. 2008. Therapeutic opportunities in biological responses of ultrasound. Ultrasonics 48(4): 271-278.

Pallant, J. 2007. SPSS Survival Manual. 3rd ed. Berkshire: McGraw-Hill.

Park, S.M., Kim, M.S., Park, S-J., Park, E.S., Choi, K-S., Kim, Y-S. \& Kim, H.R. 2013. Novel temperature-triggered liposome with high stability: Formulation, in vitro evaluation, and in vivo study combined with high-intensity focused ultrasound (HIFU). Journal of Controlled Release 170(3): 373-379.

Shibaguchi Hirotomo, Hirofumi Tsuru, Motomu Kuroki \& Masahide Kuroki. 2011. Sonodynamic cancer therapy: A non-invasive and repeatable approach using low-intensity ultrasound with a sonosensitizer. Anticancer Research 31(7): 2425-2429.

Tsao, H., Zhang, X., Majewski, P. \& Haluska, F.G. 1999. Mutational and expression analysis of the p73 gene in melanoma cell lines. Cancer Research 59(1): 172-174.

Uludag, H. \& Sefton, M.V. 1990. Colorimetric assay for cellularactivity in microcapsules. Biomaterials 11(9): 708-712.

Wang, H., Wang, X., Wang, P., Zhang, K., Yang, S. \& Liu, Q. 2013. Ultrasound enhances the efficacy of chlorin E6mediated photodynamic therapy in MDA-MB-231 cells. Ultrasound in Medicine \& Biology 39(9): 1713-1724.

Watanabe, Akihiro, Takeshi Takatera, Toshio Sato, S Takeuchim, Hiroyuki Nishimura \& Norimichi Kawashima. 2002. Study on suppression mechanism of cancer cells proliferation by ultrasound exposure for minimally invasive cancer treatment. Paper read at Ultrasonics Symposium, 2002. Proceedings. IEEE.

Wood, A.K.W. \& Sehgal, C.M. 2015. A review of low-intensity ultrasound for cancer therapy. Ultrasound in Medicine \& Biology 41(4): 905-928.

Wu, J. \& Nyborg, W. 2006. Emerging Therapeutic Ultrasound. Singapore: World Scientific Publishing Co. Pte. Ltd.

Faculty of Biosciences and Biomedical Engineering

Universiti Teknologi Malaysia

81310 UTM Skudai, Johor Darul Takzim

Malaysia

*Corresponding author; email: pauliena@utm.my

Received: 26 November 2015

Accepted: 29 September 2016 